Jacek Strojny

Politechnika Rzeszowska

Anna Prusak

Uniwersytet Ekonomiczny w Krakowie

\title{
Programowanie rozwoju przedsiębiorczości przez samorząd terytorialny
}

\section{Entrepreneurship development programming by local and regional government}

\begin{abstract}
Streszczenie
Artykuł odnosi się do mechanizmów programowania rozwoju przedsiębiorczości przez samorząd terytorialny. Osadzony jest zatem w problematyce zarządzania strategicznego w instytucjach publicznych. Przykład przedsiębiorczości, jako elementu potencjału endogenicznego podlegającego interwencji strategicznej, wybrano ze względu na rolę tego zjawiska, podkreślaną nie tylko w opracowaniach naukowych, lecz także w wielu dokumentach strategicznych i praktyce samorządowej. Podstawowym celem opracowania jest zatem określenie atrybutów skutecznego mechanizmu wspierania przedsiębiorczości przez instytucje samorządu terytorialnego. W realizacji postawionego celu pomocne są studia literatury dotyczące takich zagadnień, jak: przedsiębiorczość, zarządzanie strategiczne czy przełożenie koncepcji governance i New Public Management na praktykę zarządzania rozwojem JST. Wyjaśniając problem, nie ograniczono się tylko do rozważań teoretycznych, posłużono się również badaniem metodą case study.

Na podstawie przeprowadzonej analizy sformułowano wnioski dotyczące optymalnej procedury programowania rozwoju przedsiębiorczości na poziomie samorządu terytorialnego. Opisano zarówno narzędzia oddziaływania na przedsiębiorczość, jak i zasady planowania oraz controllingu podejmowanych działań. Sformułowano również inne zalecenia dotyczące samego mechanizmu określania odpowiedzialności za realizację celów związanych z oddziaływaniem na sferę przedsiębiorczości. Odnosząc się do tych kwestii, uwzględniono występujący w Polsce trójstopniowy podział władzy terytorialnej, a więc poziom: regionu, powiatu oraz gminy.
\end{abstract}

\begin{abstract}
The article refers to the planning of entrepreneurship development by local self-governments. It is therefore embedded in the issues of strategic management in public institutions. The example of entrepreneurship as part of the endogenous potential of strategic intervention was chosen because it emphasised the role of this phenomenon not only in scientific studies, but also in a number of strategic documents and local self-government practices.

The primary purpose of this article is therefore to define the attributes of an effective mechanism for supporting entrepreneurship by local self-government institutions. What is helpful in pursuing this objective, are literature studies on such issues as entrepreneurship, strategic management, or the transfer of the concept of governance and New Public Management to local self-government development management practice. Clarification of the issue has not been narrowed down only to theory. Content analysis was also performed with respect to the strategic documents and the case study method was also employed.
\end{abstract}


On the basis of the analysis performed, conclusions were drawn regarding the optimal procedure for programming entrepreneurship development at the local self-government level. The study also describes both the impact on entrepreneurial tools and principles for planning and controlling the actions taken. Other recommendations have also been formulated regarding the mechanism for determining responsibility for achieving objectives related to the impact on the sphere of entrepreneurship. The three-tier territorial division of power occurring in Poland (and therefore level: region, county and municipality), has been taken into account in addressing these issues.

Słowa kluczowe: planowanie strategiczne; przedsiębiorczość; samorząd terytorialny; strategie rozwoju; zarządzanie strategiczne

Keywords: entrepreneurship; local self-government; strategic management; strategic planning; strategies of development

\section{Wstęp}

Duże znaczenie, jakie ma przedsiębiorczość dla procesów rozwojowych, nie podlega dyskusjom. Można wręcz mówić o tworzeniu się paradygmatu gospodarki przedsiębiorczej (Wodecka-Hyjek, 2013; Carree, Thurik, 2003; Audretsch, Thurik, 2004). Podkreśla się w nim rolę przedsiębiorczości traktowanej jako endogeniczny czynnik rozwojowy (Wach, 2008), bazujący zarówno na jakości kapitału ludzkiego oraz społecznego, jak i zasobów rzeczowych czy finansowych. W literaturze wymienione zjawisko rozumie się wielopłaszczyznowo, wykorzystując nie tylko podejście psychologiczne, socjologiczne i menedżerskie, lecz także ekonomiczne. Z punktu widzenia niniejszego artykułu warto się skupić na przedsiębiorczości traktowanej jako jeden z fundamentów gospodarki przedsiębiorczej, a więc wykorzystując perspektywę ekonomiczną.

Mając świadomość roli przedsiębiorczości w kreowaniu wzrostu gospodarczego, należy ją brać pod uwagę jako ważny obszar oddziaływania prowadzonej przez instytucje publiczne polityki gospodarczej, a w pewnym zakresie także społecznej. Stąd też zarówno na poziomie systemu krajowego czy systemów regionalnych, jak i lokalnych, pojęcie przedsiębiorczości pojawia się bardzo często. Dążenie do jej wspierania obserwowane jest w wielu dokumentach strategicznych, w tym m.in. w:

- Strategii na rzecz inteligentnego i zrównoważonego rozwoju sprzyjającego właczeniu społecznemu Europa 2020,

- Dtugookresowej Strategii Rozwoju Kraju-Polska 2030. Trzecia fala nowoczesności,

- Strategii Rozwoju Kraju 2020 - Aktywne społeczeństwo, konkurencyjna gospodarka, sprawne państwo,

- Strategii Innowacyjności i Efektywności Gospodarki,

- Krajowej Strategii Rozwoju Regionalnego 2010-2020: Regiony, Miasta, Obszary wiejskie,

- Strategii Rozwoju Kapitatu Ludzkiego,

- strategiach regionalnych, w tym regionalnych strategiach innowacji,

- strategiach lokalnych powiatów i gmin.

Częste wskazywanie przedsiębiorczości jako obszaru szczególnego zainteresowania w ramach różnego typu strategii rozwojowych oraz na różnych poziomach systemu gospodarczego wskazuje na potrzebę zajęcia się problemem programowania rozwoju tego zjawiska. Temat ten wpisuje się w bardziej ogólne zagadnienie dotyczące mechanizmów zarządzania strategicznego na poziomie administracji publicznej. W niniejszym artykule skupiono się głównie na aktywności instytucji regionalnych i lokalnych, wskazując na ich potencjalnie niezwykle istotną rolę w tworzeniu środowiska sprzyjającego przedsiębiorczości (Szewczuk i in., 2011; 
Potoczek, 2013). Wyjaśniając możliwość wpływu samorządu na omawiane zjawisko, wykorzystano powszechnie akceptowaną koncepcję governance i New Public Management, odnoszące się do sposobów i zasad funkcjonowania instytucji publicznych w otoczeniu (Jeżowski, 2002; Wawrzyniec, 2010). Warto także wziąć pod uwagę wyzwania stojące przed samorządami w związku z doskonaleniem standardów kontroli zarządczej i wdrażaniem budżetowania zadaniowego.

Celem, który postawiono w artykule, jest zidentyfikowanie i określenie atrybutów skutecznego mechanizmu wspierania przedsiębiorczości przez instytucje samorządu terytorialnego na poziomie regionalnym i lokalnym. W badaniach wykorzystano studia literatury, w tym analizę treści dokumentów strategicznych w zakresie programowania rozwoju przedsiębiorczości. Skupiono się tutaj na kilku podstawowych aspektach. Po pierwsze, przedstawiono przedsiębiorczość z perspektywy potencjału endogenicznego. Następnie opisano rolę samorządu w programowaniu rozwoju społeczno-gospodarczego. Odniesiono się m.in. do podstaw prawnych dotyczących zarówno kwestii programowania rozwoju, jak i prowadzenia polityki w zakresie rozwoju przedsiębiorczości na poszczególnych szczeblach samorządu terytorialnego. W dalszej kolejności dokonano przeglądu wybranych strategii rozwoju, identyfikując zawarte w nich zapisy dotyczące wspierania przedsiębiorczości. W ostatnim podrozdziale artykułu opisano mechanizm programowania przedsiębiorczości, opierając się na analizie case study wybranego samorządu terytorialnego. Zaobserwowane rozwiązania uogólniono w postaci schematu stanowiącego pewnego rodzaju wytyczną do procesu programowania rozwoju w $\mathrm{JST}^{1}$.

\section{Przedsiębiorczość jako istotny element potencjału endogenicznego JST}

Przedsiębiorczość analizowana z punktu widzenia ekonomii może być traktowana jako pewnego rodzaju atrybut gospodarki (systemu gospodarczego). Takie podejście otwiera drogę do wykorzystywania takich określeń, jak przedsiębiorcza gospodarka (Entrepreneurial Economy) (Adretsh, Thurik, 2004). Można zatem stwierdzić, że przedsiębiorczość jest elementem składowym gospodarki regionalnej czy lokalnej. Co więcej, jest to element na tyle istotny, że wpływa na specyfikę pozostałych wymiarów potencjału, np. na poziom potencjału antropogenicznego, poziom innowacyjności, zamożność obywateli czy dochody instytucji publicznych (Henrekson, Stenkula, 2010; Caree, Thurik, 2010). Jest więc względem nich dominujący. Rozwijając przedstawioną kwestię, warto zatem odpowiedzieć na następujące pytania:

- Jakie elementy wchodzą w strukturę potencjału systemu gospodarczego?

- Z czego wynika dominująca rola przedsiębiorczości względem innych elementów składających się na system gospodarczy, a zatem i na gospodarkę w całości?

Odpowiadając na pierwsze pytanie, należy przyjąć, że tempo i kierunki rozwoju gospodarczego zależą od jakości oraz struktury potencjału endogenicznego. Zdolność do budowania wartości dodanej na danym terenie powoduje wzrost jakości życia mieszkańców przez stopniowe podnoszenie ich poziomu zamożności. Warto podkreślić, że współczesne gospodarki, zwłaszcza rozwinięte, mają coraz częściej charakter gospodarek lekkich, opartych na wiedzy. Zmniejsza się więc znaczenie procesów stricte związanych z przetwarzaniem surowców, rośnie natomiast waga wytworów intelektu - innowacji o różnym charakterze (Leydesdorff, 2006). Zmieniają się także warunki konkurowania w związku z rosnącą zależnością wzajemną gospodarek oraz swobodnym i masowym przepływem kapitałów między nimi. W takim środowisku przedsiębiorczość odgrywa fundamentalną rolę jako zjawisko niezbędne do kreowania wysoce konkurencyjnych i innowacyjnych zachowań.

\footnotetext{
1 JST - jednostka samorządu terytorialnego.
} 
W proponowanym tutaj ujęciu przedsiębiorczość należy rozumieć jako zjawisko, które trudno utożsamiać wyłącznie z sektorem MŚP. Ta właśnie definicja przedsiębiorczości, jako zdolności do inicjowania przedsięwzięć gospodarczych, dominuje w strategiach polskich JST. Formułując strategie, warto jednak omawiane zjawisko interpretować znacznie szerzej, uwzględniając co najmniej jego cztery wymiary:

- sektor MŚP (w szczególności przedsiębiorczość indywidualną),

- przedsiębiorczość akademicką,

- intraprzedsiębiorczość,

- przedsiębiorczość zespołową (kooperacyjną).

Pierwszy z wymienionych obszarów przedsiębiorczości nasuwa się w sposób naturalny jako jeden z podstawowych kierunków oddziaływania strategicznego. Rozwój sektora MŚP stanowi fundament tworzenia się klasy średniej, najważniejszej w społeczeństwach demokratycznych. Jest to także korzystne z perspektywy sytuacji na rynku pracy, ponieważ przedsiębiorczość indywidualna, której efektem jest założenie firmy, a więc samozatrudnienie, ogranicza podstawowy problem o charakterze społeczno-ekonomicznym: bezrobocie. Warto podkreślić, że ten obszar przedsiębiorczości jest stosunkowo łatwy do monitorowania ze względu na dostępność danych statystycznych.

Niezwykle istotne znaczenie ma również drugi wymiar przedsiębiorczości, szczególnie na poziomie regionalnym, w którym działają uczelnie. Chodzi tutaj o rozwój aktywności gospodarczej przedstawicieli świata nauki, w tym pracowników akademickich, w zakresie upowszechniania wiedzy w praktyce gospodarczej. W polskich warunkach obserwuje się znaczny potencjał rozwoju ośrodków akademickich, wynikający z upowszechnienia się modelu uczelni ukierunkowanej na komercjalizację. Władze lokalne i regionalne powinny być zatem zainteresowane udrażnianiem kanałów współpracy między ośrodkami naukowymi a przedsiębiorstwami i innymi uczestnikami życia gospodarczego. Mogą w ten sposób zwiększyć intensywność tworzenia innowacji na danym terenem, co wpisuje się w formułę rozwoju gospodarki innowacyjnej i opartej na wiedzy.

Kolejny wskazany obszar przedsiębiorczości to intraprzedsiębiorczość, a więc zjawisko o charakterze wewnątrzorganizacyjnym (Wolcott, Lippitz, 2007). Jego rozważanie w kontekście aktywności instytucji publicznych, wbrew pozorom, nie jest nieporozumieniem. Wręcz przeciwnie, należy wprowadzić ten wymiar, zwłaszcza przy analizie rozwoju intraprzedsiębiorczości pracowników administracji samorządowej. Stworzenie warunków do kreatywnego działania, wykraczającego poza wąskie ramy działań narzuconych ustawowo, wydaje się być koniecznym elementem zmian w sposobie zarządzania rozwojem społeczno-gospodarczym. Trudno oczekiwać pozytywnych efektów i skuteczności we wsparciu przedsiębiorczości lokalnej czy regionu, gdy instytucje będą działały według utartych schematów. Wykonywanie wyłącznie działań narzuconych ustawowo, nawet jeśli wiąże się ze sprawnym przebiegiem procedur administracyjnych, nie będzie wystarczające do kreowania procesów rozwojowych.

Warto także wprowadzić przedsiębiorczość zespołową - sieciową, kooperacyjną - jako wymiar istotny z punktu widzenia systemu gospodarczego. Chodzi w niej szczególnie o działania, które przynajmniej w pewnym stopniu doprowadzają do wykreowania powiązań o charakterze klastrowym. Współczesna gospodarka ma charakter sieciowy, a klastry stają się integralnym elementem życia społeczno-gospodarczego (Harmaakorpi, 2010). Możliwości wpływu samorządu na otoczenie są tutaj realne i potencjalnie dość znaczne. Co więcej, często na poziomie samorządów tego typu aktywność może się sprowadzić do wykorzystania tzw. instrumentów pozafinansowych, które generują koszty w postaci zaangażowania pracowników lub zasobów rzeczowych, nie powodują jednak znacznych wydatków inwestycyjnych. Tworzenie się kla- 
strów powinno być zatem jednym z istotnych przejawów implementacji interwencji strategicznej na każdym poziomie samorządu, a w szczególności na poziomie gmin i województw. Przedstawiony wyżej opis przedsiębiorczości z punktu widzenia polityki rozwoju społeczno-gospodarczego samorządów może stanowić podstawę do dalszych rozważań. W szczególności należy się zastanowić nad innymi elementami potencjału oraz nad ich związkiem z przedsiębiorczością. Przyjąć można, że potencjał endogeniczny zawiera elementy pogrupowane w czterech głównych wymiarach, jako:

- potencjał społeczeństwa,

- potencjał gospodarki,

- potencjał środowiska (antropogeniczny i środowiska naturalnego).

Przedsiębiorczość wchodzi w skład potencjału gospodarczego. Można tutaj rozważać jeszcze takie elementy, jak innowacyjność czy zgromadzone w danym miejscu materialne i ludzkie zasoby produkcyjne. W tym ujęciu przedsiębiorczość należy traktować jako pewnego rodzaju siłę sprawczą pozytywnych zmian (Zlotan, Audretsh, 2010). W każdym z wymienionych wyżej wymiarów przedsiębiorczość prowadzi do uzyskania efektów w postaci nowych, innowacyjnych rozwiązań oraz bardziej efektywnego wykorzystania dostępnego potencjału produkcyjnego. Szczególnie rolę tę dostrzegają wybitni myśliciele, tacy jak Drucker czy Schumpeter, którzy wskazują na to, iż umożliwia ona wykorzystywanie szans rynkowych oraz kreatywne tworzenie nowych rozwiązań na gruncie istniejących i mniej użytecznych (Drucker, 2002; Schumpeter, 1995). Przedsiębiorczość doprowadza do szybszego i trwalszego rozwoju społeczno-gospodarczego dzięki:

- tworzeniu się nowych podmiotów gospodarczych,

- skutecznej implementacji wiedzy do praktyki gospodarczej,

- wdrażaniu innowacji zarówno w przedsiębiorstwach, jak i w instytucjach publicznych,

- efektywnemu przenoszeniu części łańcucha wartości z poziomu firmy na poziom powiązań kooperacyjnych.

Warto jednak pamiętać o tym, że przedsiębiorczość ma swoje źródła w wymiarze społecznym. Takie jej elementy, jak kapitał ludzki i społeczny wpływają znacząco na jakość zachowań ludzkich. Rozwój kompetencji, w tym stricte ekonomicznych, z całą pewnością stymuluje postawy przedsiębiorcze, ułatwiając ich uzewnętrznienie w postaci zakładania własnych firm, komercjalizacji wyników badań czy wielu innych działań podejmowanych w ramach wymienionych wymiarów przedsiębiorczości. To przejście z psychologicznego do behawioralnego wymiaru przedsiębiorczości jest możliwe głównie w sprzyjającym otoczeniu społecznym. Społeczeństwo obywatelskie, w którym relatywnie niskie są bariery dla kreatywności i innowacyjności oraz w którym wspiera się aktywność i determinację w realizacji celów, z całą pewnością stanowi dobrą bazę dla przedsiębiorczości jako zjawiska o charakterze ekonomicznym (Potoczek, Pyrzyk, 2013).

Z drugiej strony przedsiębiorczość może być także determinantą potencjału antropogenicznego i środowiska naturalnego. Jej wpływ nie jest jednak jednoznaczny, głównie ze względu na trudność w wyeliminowaniu negatywnych skutków antropogenezy dla przyrody. Przedsiębiorczość, prowadząc do intensywnego wytwarzania wartości dodanej, sprzyja bogaceniu się społeczeństwa, a zatem prowadzi także do intensyfikacji rozwoju potencjału antropogenicznego. Jednocześnie generuje to również negatywne skutki w postaci zanieczyszczenia środowiska naturalnego oraz ograniczenia terenów przyrodniczych. Warto o tym pamiętać, tworząc strategie rozwoju, które co do zasady muszą mieć charakter zrównoważony. W tworzeniu planów rozwojowych zachodzi więc istotna sprzeczność między różnymi celami rozwojowymi, którą należy rozstrzygać na podstawie przyjętych priorytetów strategicznych. 
Bardzo ważnym, z punktu widzenia autorów niniejszego artykułu, jest kolejny element środowiska, czyli potencjał instytucjonalny. Można go utożsamiać, w ujęciu szerokim, z otoczeniem okołobiznesowym albo, w ujęciu wąskim, z jakością administracji publicznej. Takie ograniczone rozumienie wymienionego elementu przyjęto w niniejszym tekście. Należy podkreślić, że administracja samorządowa dysponuje szeregiem instrumentów, za pomocą których jest w stanie determinować każdy z elementów potencjału endogenicznego, w tym przedsiębiorczość. Można je podzielić na działania o charakterze finansowym: dochodowe i wydatkowe, oraz pozafinansowym: działania o charakterze inicjacyjnym i sieciowym (Potoczek, 2013). W większości przypadków mają one jednak charakter pośredni, a więc pozwalają wpływać na warunki rozwoju przedsiębiorczości: klimat, jakość infrastruktury itd. Istnieją oczywiście także narzędzia bezpośredniego oddziaływania, np. podatki od nieruchomości, podatki dochodowe w specjalnych strefach ekonomicznych czy bezpośrednie wsparcie przedsiębiorczości z programów Unii Europejskiej. Skuteczność i efektywność ich wykorzystania uzależniona jest od wielu czynników. Część z nich wynika z otoczenia krajowego i wiąże się w szczególności z jakością prawa oraz relacjami między administracją centralną a samorządową, a także między administracją publiczną a przedsiębiorcami (aktualnymi i potencjalnymi). Nie ulega jednak wątpliwości, że samorząd, po kilkunastu latach funkcjonowania w obecnym, trójszczeblowym układzie, jest już dojrzały instytucjonalnie. Trzeba więc oczekiwać umiejętnego równoważenia działań związanych z zapewnianiem wykonywania obowiązków określonych ustawowo z działaniami, które wykraczają poza te ramy, a koniecznych z punktu widzenia kreowania procesów rozwojowych.

\section{Podstawy aktywności samorządu w zakresie programowania przedsiębiorczości}

Kształtowanie warunków sprzyjających rozwojowi przedsiębiorczości należy do podstawowych celów samorządu terytorialnego, zarówno na szczeblu regionalnym, jak i lokalnym. Jest to uzasadnione ze względu na opisane wcześniej aspekty związane z kształtowaniem rozwoju społeczno-gospodarczego. Tego typu aktywność powinna być także osadzona w systemie prawnym determinującym działania samorządów. Można się o tym przekonać, dokonując krótkiego przeglądu podstawowych aktów prawnych, takich, jak: Ustawa o samorządzie województwa, Ustawa o samorzadzie powiatowym oraz Ustawa o samorzadzie gminnym.

W pierwszej z wymienionych ustaw określa się m.in. zakres działalności samorządu województwa, zarówno w wymiarze strategicznym, jak i operacyjnym. W art. 11 Ustawy o samorządzie województwa (1998) wskazuje się na konieczność określania strategii rozwoju, która powinna uwzględniać m.in. takie cele, jak:

- pobudzanie aktywności gospodarczej,

- podnoszenie poziomu konkurencyjności i innowacyjności gospodarki województwa.

Programując rozwój gospodarczy, każdy z samorządów powinien się odnosić do wymienionych wyżej obszarów, określając także działania niezbędne do ich osiągnięcia. Dla przykładu w Strategii Rozwoju Województwa - Podkarpackie 2020 uwzględniono całą wiązkę celów ukierunkowanych na rozwój przedsiębiorczości lub jej otoczenia, w ramach Priorytetu I: Konkurencyjna i innowacyjna gospodarka (Strategia Rozwoju Województwa..., 2013). Sformułowane tam cele szczegółowe uwzględniają aspekt kreowania otoczenia innowacyjnego (przedsiębiorczość akademicka, intraprzedsiębiorczość i przedsiębiorczość sieciowa). Wymieniony już art. 11 wskazuje na zadania w zakresie polityki rozwoju województwa, które obejmują:

- tworzenie warunków rozwoju gospodarczego, w tym kreowanie rynku pracy,

- wspieranie rozwoju nauki i współpracy między sferą nauki i gospodarki,

- popieranie postępu technologicznego oraz innowacji. 
Zapisy odnoszące się do aktywności samorządu wojewódzkiego na poziomie strategicznym nie są jednak w pełni przenoszone na poziom działań operacyjnych, co w rzeczywistości nieco utrudnia bezpośrednie zaangażowanie się w proces wspierania przedsiębiorczości. Wśród zadań o charakterze wojewódzkim, w art. 14 Ustawy o samorządzie województwa, nie wymienia się bowiem takich, które odnosiłyby się bezpośrednio do sfery gospodarczej czy stricte któregoś z wymiarów przedsiębiorczości.

Samorządy na poziomie lokalnym - powiatowe i gminne - nie mają ustawowo narzuconego obowiązku tworzenia strategii. Zwyczajowo jednak w większości tego typu jednostek w Polsce tworzy się różnego rodzaju dokumenty strategiczne, w tym główne, które określa się najczęściej jako strategie rozwoju społeczno-gospodarczego. Ustawa o samorządzie powiatowym nakłada natomiast na tego typu jednostki zadania publiczne o tzw. charakterze ponadgminnym. Podobnie jak w przypadku województw, również tutaj spośród 26. zadań wymienionych w art. 4 żadne nie dotyczy bezpośrednio spraw związanych ze wspieraniem rozwoju potencjału gospodarczego, a zatem także przedsiębiorczości.

Mimo braku obowiązków prawnych znaczna część powiatów w dokumentach strategicznych odnosi się do problematyki rozwoju przedsiębiorczości, określając nawet cele w tym obszarze. Przykładem może być tutaj Strategia Rozwoju Społeczno-Gospodarczego Powiatu Nowotarskiego 2015-2020. W dokumencie tym odniesiono się do przedsiębiorczości w kilku punktach. Po pierwsze, określono obszar pod nazwą Powiat przedsiębiorczy i innowacyjny, podkreślając tym samym ważną rolę tego wymiaru rozwoju. W analizie priorytetów rozwojowych wskazano także przedsiębiorczość jako element najważniejszy, zaś innowacyjność przedsiębiorstw znalazła się na czwartym miejscu pod względem istotności (Strategia Rozwoju Społeczno-Gospodarczego Powiatu..., 2014).

Najpełniejszy katalog zadań publicznych został jednak określony na poziomie gminy, która stanowi podstawowy typ jednostki samorządowej. Zgodnie z art. 6. Ustawy o samorzadzie gminnym do jej zakresu działania należą, ,wszystkie sprawy publiczne o znaczeniu lokalnym, niezastrzeżone ustawami na rzecz innych podmiotów". W art. 7 opisano najważniejsze - zdaniem ustawodawcy - zadania własne gminy, wśród których również nie wymieniono działań bezpośrednio związanych z oddziaływaniem czy to na sferę gospodarczą, czy na przedsiębiorczość lub innowacyjność.

Niezależnie od tego samorządy na poziomie gminnym także umieszczają w dokumentach strategicznych odniesienia do przedsiębiorczości. Przykładem mogą być tutaj Gliwice, które w znacznym stopniu opierają swoją strategię na polityce kreowania przedsiębiorczości i innowacyjności. Odniesienia do tych obszarów znajdują się w wizji rozwoju do 2022 r., w którą wpisuje się dążenie do utrzymania wysokiego tempa rozwoju gospodarczego, bycia liderem w zakresie wdrażania gospodarki innowacyjnej oraz podsycania lokalnego potencjału przedsiębiorczości, również w wymiarze akademickim (Strategia Zintegrowanego ..., 2011). Budowa nowoczesnych struktur gospodarczych jest także pierwszym celem strategicznym miasta. Przekłada się to na formułowanie celów oraz programów strategicznych. W badanym mieście stworzono program adresowany do przedsiębiorczości pod nazwą Przedsiębiorcze Gliwice.

Oczywiście, na każdym z wymienionych poziomów samorządu terytorialnego, mimo braku bezpośredniego odniesienia do przedsiębiorczości w ustawach podstawowych (w szczególności w nawiązaniu do listy zadań publicznych), istnieje możliwość realizacji na poziomie operacyjnym zadań ukierunkowanych na rozwój przedsiębiorczości. Po pierwsze, mogą one mieć charakter projektów współfinansowanych z Unii Europejskiej, a ukierunkowanych np. na kreowanie samozatrudnienia, tworzenie powiązań kooperacyjnych czy rozwój współpracy nauki z gospodarką. Po drugie, istnieje możliwość wspierania rozwoju przedsiębiorczości w ramach 
innych zadań publicznych, np.: zapewnienia ładu przestrzennego, edukacji publicznej, infrastruktury komunikacyjnej, infrastruktury komunalnej, pobudzania aktywności obywatelskiej, wspierania kultury.

Nie ulega jednak wątpliwości, że istnieje rozdźwięk między potrzebami długofalowej polityki rozwojowej, w tym związanej z oddziaływaniem na sferę gospodarki, a prawnym osadzeniem bieżącego działania w tym zakresie. Ustawodawca, przez zdefiniowanie katalogu zadań publicznych wykonywanych na poszczególnych poziomach samorządu terytorialnego, wskazuje bowiem kierunek wydatkowania środków finansowych i koncentracji innych zasobów: ludzkich i materialnych. Z tego wynikają konsekwencje w postaci określonych rozwiązań organizacyjnych w instytucjach samorządowych. Struktury organizacyjne, a zatem także opisy stanowisk pracy i zakresy czynności poszczególnych pracowników, odzwierciedlają bowiem merytoryczny zakres działania danej jednostki samorządowej. W takiej sytuacji, mimo odnoszenia się do przedsiębiorczości w strategiach rozwoju, realizacja skoordynowanej polityki w tym zakresie jest bardzo trudna. Wdrożenie zapisów strategicznych wymaga bowiem ich przełożenia na realne działania - procesy i projekty - oraz realną odpowiedzialność - komórki lub stanowiska odpowiedzialne za koordynację wdrożenia polityki rozwoju w zakresie przedsiębiorczości. Uwagi stanowią inspirację do budowania ogólnego modelu programowania rozwoju przedsiębiorczości, który zniweluje lukę w obszarze systemu prawnego za pomocą rozwiązań proceduralnych i wewnątrzorganizacyjnych.

\section{Model programowania przedsiębiorczości przez samorząd terytorialny}

W niniejszym rozdziale przygotowano założenia dotyczące procesu programowania przedsiębiorczości, uwzględniając założenia orientacji zadaniowej organizacji (Strojny, 2012, 2013). Tego typu podejście uwzględnia następujące elementy:

- strategię opartą na priorytetach,

- budżetowanie zadaniowe,

- system zarządzania projektami,

- system kontroli zarządczej,

- strukturę macierzową,

- proefektywnościowy system wynagrodzeń,

- $\quad$ specjalistyczny system IT wspomagający zarządzanie zadaniami (Strojny, 2012).

Ryc. 1. Schemat modelu programowania rozwoju przedsiębiorczości przez samorząd terytorialny
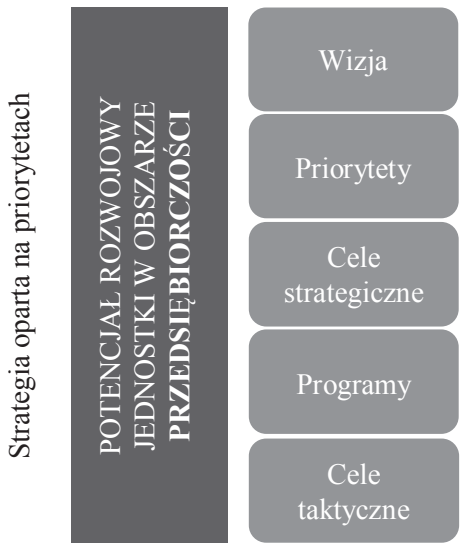

Uwarunkowania realizacji strategii

System zarz. projektami

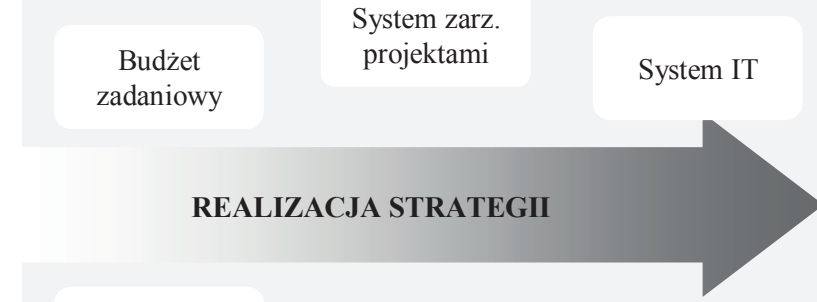

Struktura macierzowa

System kontr. zarządczej

Proefekt. sys. wynagrodzeń

Źródło: opracowanie własne na podstawie: Strojny (2012). 
Mają na uwadze wyżej wymienione elementy, można przygotować schemat modelu programowania przedsiębiorczości, uwzględniając zarówno aspekt strategiczny, jak i jego przełożenie na wymiar taktyczny i operacyjny zarządzania (rys. 1).

Punktem wyjścia w proponowanym modelu jest przyjęcie założenia, że strategia rozwoju jednostki samorządu terytorialnego odnosi się do kreowania pozytywnych zmian w ramach wewnętrznego potencjału rozwojowego (Dziemianowicz, 2012). Dzięki odpowiednio zaplanowanym i realizowanym zadaniom możliwe jest uzyskanie oczekiwanych efektów, które odpowiadają przyjętym celom strategicznym i taktycznym ${ }^{2}$. W takim podejściu należy przyjąć, że istnieje taki obszar potencjału endogenicznego, który dotyczy bezpośrednio zjawiska przedsiębiorczości. Warto w strategii zdefiniować, co w danej jednostce rozumie się pod tym pojęciem. Jeśli przedsiębiorczość jest uwzględniona jako element potencjału, to w analizie strategicznej należy poddać ocenie sytuację w tym obszarze. Warto tutaj zastosować bardziej zaawansowane postępowanie oparte na procedurze badań porównawczych - element metody benchmarkingu, polegającej na doskonaleniu się przez porównywanie się i inspirowanie rozwiązaniami wykorzystywanymi przez innych (Boxwell, 1994). Dzięki temu uzyskuje się obiektywną ocenę nie tylko dotyczącą kierunku i tempa zmian wewnętrznych, lecz także ich porównanie ze zmianami zachodzącymi w pozostałych jednostkach. Taka analiza umożliwia zidentyfikowanie specyficznych warunków wewnętrznych panujących we wzorcowym samorządzie - takim, który uzyskuje najlepsze efekty rozwojowe. Na tej podstawie należy zdefiniować wszystkie elementy w części strategii poświęconej programowaniu rozwoju (planom rozwojowym).

Pierwszym krokiem jest tutaj sformułowanie wizji, a więc opisu docelowego stanu osiągniętego w danej jednostce samorządowej na koniec okresu programowania (Gawroński, 2010). W ramach wizji warto odnieść się do stanu przedsiębiorczości, wskazując na wartości jej wybranych parametrów, np. stan sektora MŚP. Następnie należy zweryfikować priorytety strategiczne. Dobrym rozwiązaniem jest wykorzystanie elementów potencjału rozwojowego zidentyfikowanych w fazie analizy. Jedną z metod, która umożliwia ocenę istotności poszczególnych elementów potencjału, jest metoda AHP (Analytic Hierarchy Process) (Saaty, 2000, 2014; Prusak, Stefanow, 2014). Jest to jedna z eksperckich metod podejmowania decyzji. W wyniku jej zastosowania możliwe jest uzyskanie rankingu priorytetów.

Przyjmując, że przedsiębiorczość należy do najważniejszych obszarów interwencji strategicznej, należy przejść do określenia celów o charakterze strategicznym. W prezentowanej w niniejszym artykule koncepcji cele te mają charakter ogólny, a ich pomiaru dokonuje się za pomocą danych statystycznych. Mogą one być sformułowane w następujący sposób:

- liczba podmiotów sektora prywatnego w ... r. na poziomie min. ... stanu z 2013 r.,

- udział spółek handlowych w podmiotach sektora prywatnego powyżej ...\% na koniec ... r.

Samorząd nie dysponuje najczęściej narzędziami, które umożliwiłyby osiągnięcie tak sformułowanych celów strategicznych. Dlatego też mają one raczej charakter kontekstowy i określają ogólną kondycję jakiegoś obszaru potencjału endogenicznego, np. przedsiębiorczości. Ich wyznaczenie pozwala na monitorowanie sytuacji w danej jednostce samorządowej przez

\footnotetext{
${ }^{2} \mathrm{~W}$ przyjętej koncepcji cele strategiczne określa się raczej na czas realizacji strategii. Mają one także raczej charakter kontekstowy - wiążą się z ogólną kondycją rozwojową jednostki samorządowej. Natomiast cele taktyczne mogą być formułowane na okres trwania programu rozwojowego. Są również bardziej szczegółowe i bezpośrednio odnoszą się do narzędzi, którymi dysponuje samorząd terytorialny danego szczebla. Muszą one zatem bezpośrednio dotyczyć działań, które zostaną podjęte w ramach implementacji strategii (programy i projekty).
} 
porównywanie się do jednostek benchmarkowych w trakcie realizacji strategii. Dlatego też wykorzystanie danych statystycznych jako mierników celów strategicznych wydaje się konieczne. Samorząd terytorialny ma jednak ograniczony zakres działania, zatem cele strategiczne może realizować zazwyczaj pośrednio, przez podejmowanie innych działań, np. inwestycji, promocję produktów lokalnych, inicjowanie powiązań klastrowych itd. W odniesieniu do priorytetowych obszarów zadania te powinny mieć charakter programów rozwojowych. Program to takie przedsięwzięcie długookresowe, które skupia wiele projektów realizowanych w różnym czasie, ale ukierunkowanych na realizację danego celu strategicznego (Dałkowski i in., 2009). W takim ujęciu programowanie strategii powinno się opierać głównie na zdefiniowaniu wiązki programów rozwojowych oraz określeniu dla nich takich celów taktycznych, których realizacja przełoży się na realizację celu strategicznego. Przykładowe cele taktyczne w ramach programu ukierunkowanego na rozwój przedsiębiorczości można sformułować następująco:

- do ...r. rozpocznie działalność min. ... klastrów ...,

- do ...r. rozpocznie działalność min. ... inkubatorów przedsiębiorczości,

- do 2022 r. uruchomionych zostanie min. ... spółdzielni socjalnych.

Wprowadzenie strategii opartej na podejściu zadaniowym, a więc wykorzystującej programy rozwojowe jako główne narzędzie oddziaływania na otoczenie, ma pewne konsekwencje w odniesieniu do całego systemu organizacyjnego instytucji samorządowych. Po pierwsze, program należy zaplanować zgodnie z podejściem projektowym (systemem zarządzania projektami). W szczególności trzeba stworzyć planowaną listę projektów w ramach programu rozwojowego, następnie przygotować harmonogram ich realizacji oraz podstawowe założenia budżetowe. Tak stworzony budżet programu stanowi część budżetu strategii i powinien znaleźć odzwierciedlenie $\mathrm{w}$ budżecie rocznym samorządu, który również powinien być opracowany w układzie zadaniowym. Wówczas uzyskuje się spójność między planowaniem finansowym na poziomie strategicznym a bieżącymi decyzjami finansowymi w danym roku budżetowym. Ze względu na dużą złożoność procesu planowania oraz konieczność operowania znaczną ilością danych warto wykorzystać specjalistyczne oprogramowanie IT, pozwalające na automatyzację harmonogramowania i budżetowania.

Kolejnym ważnym aspektem jest określenie odpowiedzialności za dany obszar oddziaływania strategicznego. W przypadku podejścia proponowanego w artykule osobą odpowiedzialną za rozwój przedsiębiorczości jest kierownik programu rozwojowego ukierunkowanego na ten element potencjału rozwojowego. Autorzy tekstu sugerują, żeby osoba pełniąca tę funkcję należała do wyższego lub średniego kierownictwa: kierownik jednostki bądź jego zastępca, kierownik jednostki organizacyjnej albo kierownik komórki organizacyjnej. Co więcej działania związane z koordynacją polityki rozwojowej dotyczącej wsparcia przedsiębiorczości powinny zostać wpisane w zakres obowiązków na tym stanowisku. Wartym uwagi, choć trudnym do wdrożenia w samorządzie, jest proefektywnościowy system wynagrodzeń. Powinien istnieć związek między wysokością wynagrodzenia a skutecznością osiągania celów przyjętych w strategii. Należy podkreślić, że wprowadzenie takiego rozwiązania powoduje jeszcze jeden skutek w postaci motywowania do aktywności i kreatywności. Może zatem wiązać się z rozwojem intraprzedsiębiorczości w instytucjach samorządu terytorialnego.

Prezentowany model programowania strategicznego wykorzystuje przykład przedsiębiorczości, ale ma charakter ogólny i dotyczy całej strategii. Jego wdrożenie udrażnia proces zarządzania, wiążąc wymiar strategiczny z operacyjnym. Dzięki temu uzyskuje się możliwość faktycznego wdrożenia standardów kontroli zarządczej (Skica, Strojny, 2013). Ich podstawową zaletą jest bowiem celowość, efektywność i skuteczność działania. Strategia oparta na podejściu 
projektowym oraz towarzysząca jej zmiana instytucji samorządowej w organizację zarządzaną zadaniowo stwarzają właśnie takie możliwości.

\section{Podsumowanie}

Wdrożenie mechanizmu programowania rozwoju przedstawionego w niniejszym artykule jest czynnością relatywnie prostą w wymiarze planowania strategii oraz niezwykle trudną w odniesieniu do tworzenia warunków sprzyjających podejściu zadaniowemu. Warto jednak traktować oba wymiary jako integralną całość. Zmiana sposobu przygotowania dokumentu strategicznego, wprowadzenie czytelnych i mierzalnych celów oraz zdefiniowanie programów nie wystarczą. Konieczne jest także redefiniowanie sposobu funkcjonowania samorządu.

Po pierwsze, należy odejść od administracyjnej formuły działania, w głównej mierze opartej na dążeniu do zapewnienia zapisów ustawowych. Konieczne jest zatem poszukiwanie odpowiedzi nie tylko na pytanie, czego oczekuje ustawodawca, lecz także - czego oczekuje społeczność samorządowa oraz czego wymaga proces rozwoju.

Druga istotna kwestia to uaktywnienie wewnętrznej przedsiębiorczości pracowników samorządowych. Wymaga to zarówno zmian w zakresie organizacji pracy, oceny i motywowania, jak i wykorzystywanych narzędzi pracy. W takim wypadku przywołana w artykule koncepcja orientacji zadaniowej wydaje się bardzo dobrym i, przede wszystkim, skutecznym rozwiązaniem.

Wymienione wyżej obszary wskazują na zasadność prowadzenia dalszych badań, pogłębiających wiedzę na temat prawnych i organizacyjnych uwarunkowań kreowania przedsiębiorczości przez administrację samorządową. W szczególności należy odpowiedzieć na następujące pytania:

1. W jaki sposób zorganizować i skoordynować politykę rozwoju przedsiębiorczości przy uwzględnieniu prawnych ograniczeń funkcjonowania JST na poszczególnych poziomach?,

2. Jakie metody zarządzania w efektywny sposób wspomagają implementację planów strategicznych, w tym tych odnoszących się do przedsiębiorczości?,

3. Które narzędzia kreowania intraprzedsiębiorczości mogą zostać wprowadzone w instytucjach samorządowej administracji publicznej przy uwzględnieniu istniejących warunków prawnych?.

Wymienione pytania są istotne nie tylko z punktu widzenia rozwoju nauki. Szczególne znaczenie mają również dla praktyki zarządzania. Należy je więc traktować nie tylko jako pytania badawcze, lecz także - implementacyjne.

\section{Literatura \\ References}

Audretsch, D., Thurik, R. (2004). A model of Entrepreneurial Economy. The Papers of Entrepreneurschip, Growth and Public Policy. Jena: Max Planck Institute.

Boxwell, R.J. (1994). Benchmarking for Competitive Advantage. New York: McGraw-Hill.

Carree, M.A., Thurik, A.R. (2010). The impact of Entrepreneurship on Economic Growth. W: J.A Zlotan, D.B. Audretsch (red.) (2010). Handbook of Entrepreneurship Research. II ed., New York-Dordrecht-Heidelberg-London: Springer, 557-594.

Dałkowski, B., Staśto, L., Zalewski, M. (red.) (2009). Polskie Wytyczne Kompetenc ji IPMA. Gdańsk: Stowarzyszenie Project Management Polska.

Dlugookresowa Strategia Rozwoju Kraju - Polska 2030. Trzecia fala nowoczesności. (2013). Warszawa: Ministerstwo Administracji i Cyfryzacji. 
Drucker, P.F. (2002). Myśli przewodnie Druckera. Warszawa: MT Biznes.

Dzimianowicz, W. (2012). Planowanie strategiczne: poradnik dla pracowników administracji publicznej. Warszawa: MRR.

Gawroński, H. (2010). Zarządzanie strategiczne w samorzadach lokalnych. Warszawa: Wolters Kluwer Polska.

Harmaakorpi, V. (2010). Metoda Platformy Rozwoju Regionalnego jako narzędzie polityki innowacyjnej. Warszawa: PARP.

Henrekson, M., Stenkula, M. (2010). Entrepreneurship and Public Policy. W: J.A Zlotan, D.B. Audretsch (red.) (2010). Handbook of Entrepreneurship Research. II ed., New York-Dordrecht-Heidelberg-London: Springer, 639-660.

Jeżowski, P. (2002). New Public Management - nowy paradygmat zarządzania w sektorze publicznym. W: P. Jeżowski (red.), Zarządzanie w sektorze publicznym - rozwój zrównoważony - metody wyceny. Warszawa: Wydawnictwo SGH.

Krajowa Strategia Rozwoju Regionalnego 2010-2020: Regiony, Miasta, Obszary Wiejskie. (2010). Warszawa: Ministerstwo Rozwoju Regionalnego.

Leydesdorff, L. (2006). The Kowledge-Based Economy: Modeled, Measured, Simulated. Boca Raton: Universal Publishers,.

Potoczek, A. (2013). Zarządzanie jednostka terytorialna. Wybrane zagadnienia. Bydgoszcz: Wydawnictwo Uczelniane Wyższej Szkoły Gospodarki.

Potoczek, A., Pyrzyk, I. (2013). Administracja i zarzadzanie. Perspektywa Społeczna i organizacyjna. Włocławek: Wyższa Szkoła Humanistyczno-Ekonomiczna.

Prusak, A., Stefanów, P. (2014). AHP - analityczny proces hierarchiczny. Budowa i analiza modeli decyzyjnych krok po kroku. Wyd 1., Warszawa: C.H. Beck.

Saaty, T. (2014). The Neural Network Process, Generalization of the AHP and ANP to Continuous Case of Neural Firing. Pitzburg: RWS Publications.

Saaty, T. (2000). Fundamentals of Decision Making and Priority Theory with the Analytic Hierarchy Process. 2nd ed., Pitzburg: RWS Publications, 527.

Schumpeter, J.A. (1995). Kapitalizm, socjalizm, demokracja. Warszawa: Wyd. Naukowe PWN.

Skica, T., Strojny, J. (2013). Orientacja projektowa jako systemowe wspieranie kontroli zarządczej w jednostkach samorządu terytorialnego. Samorzad Terytorialny, 4, 49-63.

Strategia na rzecz inteligentnego i zrównoważonego rozwoju sprzyjającego włączeniu społecznemu Europa 2020. (2010). Bruksela: Komisja Europejska.

Strategia Rozwoju Kapitału Ludzkiego. (2013). Warszawa: Ministerstwo Pracy i Polityki Społecznej.

Strategia Rozwoju Kraju 2020. Aktywne społeczeństwo, konkurencyjna gospodarka, sprawne państwo. (2012). Warszawa: Ministerstwo Rozwoju Regionalnego.

Strategia Rozwoju Społeczno-Gospodarczego Powiatu Nowotarskiego. (2014). Nowy Targ: Starostwo Powiatowe.

Strategia Rozwoju Województwa - Podkarpackie 2020. (2013). Rzeszów: Samorząd Województwa Podkarpackiego.

Strategia Innowacyjności i Efektywności Gospodarki. (2013). Warszawa: Ministerstwo Gospodarki.

Strategia Zintegrowanego i Zrównoważonego Rozwoju Miasta Gliwice do roku 2020. (2011). Gliwice: Samorząd Miasta.

Strojny, J. (2012). Innowacyjne zarządzanie regionem, powiatem i gmina. Rzeszów: Politechnika Rzeszowska.

Strojny, J. (2013). Orientacja zadaniowa jako systemowe podejście do zarządzania oparte na filozofii zarządzania projektami. W: T. Listwan, Ł. Sułkowski, Ekonomiczne i sprawnościowe problemy zarządzania projektami. Łódź: Społeczna Akademia Nauk, 185-196.

Szewczuk, A., Kogut-Jaworska, M., Zioło, M. (2011). Rozwój lokalny i regionalny. Teoria i praktyka. Warszawa: Wydawnictwo C.H. Beck.

Ustawa z dnia 5 czerwca 1998 r. o samorządzie województwa. Dz.U. $1998 \mathrm{nr}$ 91, poz. 576.

Ustawa z dnia 5 czerwca 1999 r. o samorzadzie powiatowym. Dz.U. 1998 nr 91, poz. 578.

Ustawa z dnia 8 marca 1990 r. o samorzadzie gminnym. Dz.U. $1990 \mathrm{nr}$ 16, poz. 95. 
Wach, K. (2008) Regionalne otoczenie małych i średnich przedsiębiorstw. Kraków: Wydawnictwo UEK. Wawrzyniec, R. (2010). Koncepcja governance i jej zastosowanie - od instytucji międzynarodowych do niższych szczebli władzy. Acta Universitatis Lodziensis.

Wodecka-Hyjek, A. (2013). Paradygmat przedsiębiorczości w perspektywie wybranych reprezentantów klasycznej szkoły organizacji i zarządzania. Studia i Materiały. Miscellanea Oeconomicae, 2, Kielce: Uniwersytet Jana Kochanowskiego.

Wolcott, R.C, Lippitz, M.J. (2007). The Four Models of Corporate Entrepreneurship. MIT Sloan Management Review, 74-83.

Jacek Strojny, ekonomista, doktor nauk ekonomicznych w zakresie nauk o zarządzaniu, adiunkt w Katedrze Ekonomii Wydziału Zarządzania Politechniki Rzeszowskiej, Pełnomocnik dziekana ds. projektów rozwojowych i komercjalizacji badań. Specjalizuje się w problematyce implementacji metod i technik zarządzania w przedsiębiorstwach i jednostkach administracji publicznej, zarówno na poziomie zarządzania strategicznego, jak i operacyjnego. Jest autorem kilkudziesięciu publikacji dotyczących przedsiębiorczości i innowacji, rozwoju regionalnego i lokalnego oraz zarządzania projektami. Koordynował projekty wdrożenia innowacyjnych systemów zarządzania w kilkudziesięciu przedsiębiorstwach i samorządach. Jest także autorem strategii rozwoju lokalnego na poziomie gminnym i powiatowym.

Jacek Strojny, economist, PhD, Assistant Professor in the Department of Economics, Faculty of Management, Rzeszow University of Technology, The Deans Plenipotentiary for Development and Commercialization. He specializes in methods and techniques implementation in companies and public administration institutions on the strategic and operational level. The author of several dozen publications related to entrepreneurship, innovations, local and regional development and project management as well. He was a coordinator of many innovative implementation projects in companies and public institutions. He is the author of strategic documents prepared on the municipality and district level.

Adres/Address: Politechnika Rzeszowska

al. Powstańców Warszawy 12

35-959 Rzeszów, Polska

e-mail: jstrojny@prz.edu.pl

Anna Prusak, adiunkt w Katedrze Zarządzania Jakością Uniwersytetu Ekonomicznego w Krakowie oraz specjalista ds. projektów badawczych finansowanych ze źródeł krajowych i międzynarodowych na wydziale Nauk o Zdrowiu CMUJ. Ma doświadczenie jako ekspert i partner w licznych międzynarodowych i krajowych projektach badawczych. Od wielu lat współpracownik Stowarzyszenia „Edukacja dla Przedsiębiorczości” w Krakowie, w ramach projektów obejmujących współpracę nauka - biznes. Członek stowarzyszony Krajowej Rady Koordynatorów Projektów Badawczych (KRAB). Jej doświadczenie zagraniczne obejmuje m.in. kilkuletnią pracę na Uniwersytecie Rolniczym w Atenach w ramach dużych projektów badawczych (Program Ramowy 5 i 6) oraz staże badawcze w Instytucie Fraunhofera (Lipsk) i IBM Watson Research Centre (Nowy York), organizowane przez NCBR w ramach projektu SIMS (Science Infrastructure Management Support). Naukowo zajmuje się metodami wspomagającymi podejmowanie decyzji. W tym obszarze otrzymała w 2010 r. wyróżnienie za szczególne osiągnięcia naukowe przyznane przez Komitet Nauk Rolniczych, Leśnych i Weterynaryjnych Polskiej Akademii Nauk. Obecnie prowadzi projekt badawczy NCN Nr 2011/01/D/HS4/04006: „Czynniki wpływające na zgodność porównań parami w metodach analitycznego procesu hierarchicznego i sieciowego (AHP/ANP)". Autorka lub współautorka wielu publikacji, 
w tym artykułów publikowanych w wysokopunktowanych czasopismach zagranicznych. Współautorka książki pt. AHP - analityczny proces hierarchiczny. Budowa i analiza modeli decyzyjnych krok po kroku, wydanej nakładem wydawnictwa C.H. Beck w 2014 r.

Anna Prusak, assistant professor at the Department of Quality Management, Cracow University of Economics. Consultant of the research projects at Jagiellonian University Medical College in Krakow. Her other experience in project management involve working for the Association "Education for Entrepreneurship" in the projects involving cooperation between business and science. She also worked in numerous international and national research projects. She is a mem include multicriteria decision support methods. In 2010, awarded a prize of the Polish Academy of Sciences, Committee of Agricultural, Forestry and Veterinary Sciences, for her scientific achievements. Currently she coordinates the research project (NCN 2011/01/D/HS4/04006) titled: „Factors influcencing the consistency of judgments in the analytic hierarchy and network processes (AHP/ANP)". Author and co-author of many publications in the area of consumer research, decision making and AHP/ANP methods. In 2014, her book titled "The Analytic Hierarchy Process. A step by step approach to decision making models" was published by C.H. Beck in 2014 .

Adres/Address: Uniwersytet Ekonomiczny

ul. Rakowicka 27

31-510 Kraków, Polska

e-mail: anna.prusak@uek.krakow.pl 